\title{
Evaluation of Diesel Exhaust Exposures at Multiple Fire Stations in a City Fire Department
}

James Couch, PhD, CIH, CSP, REHS/RS Kendra Broadwater, MPH Marie A. de Perio, MD

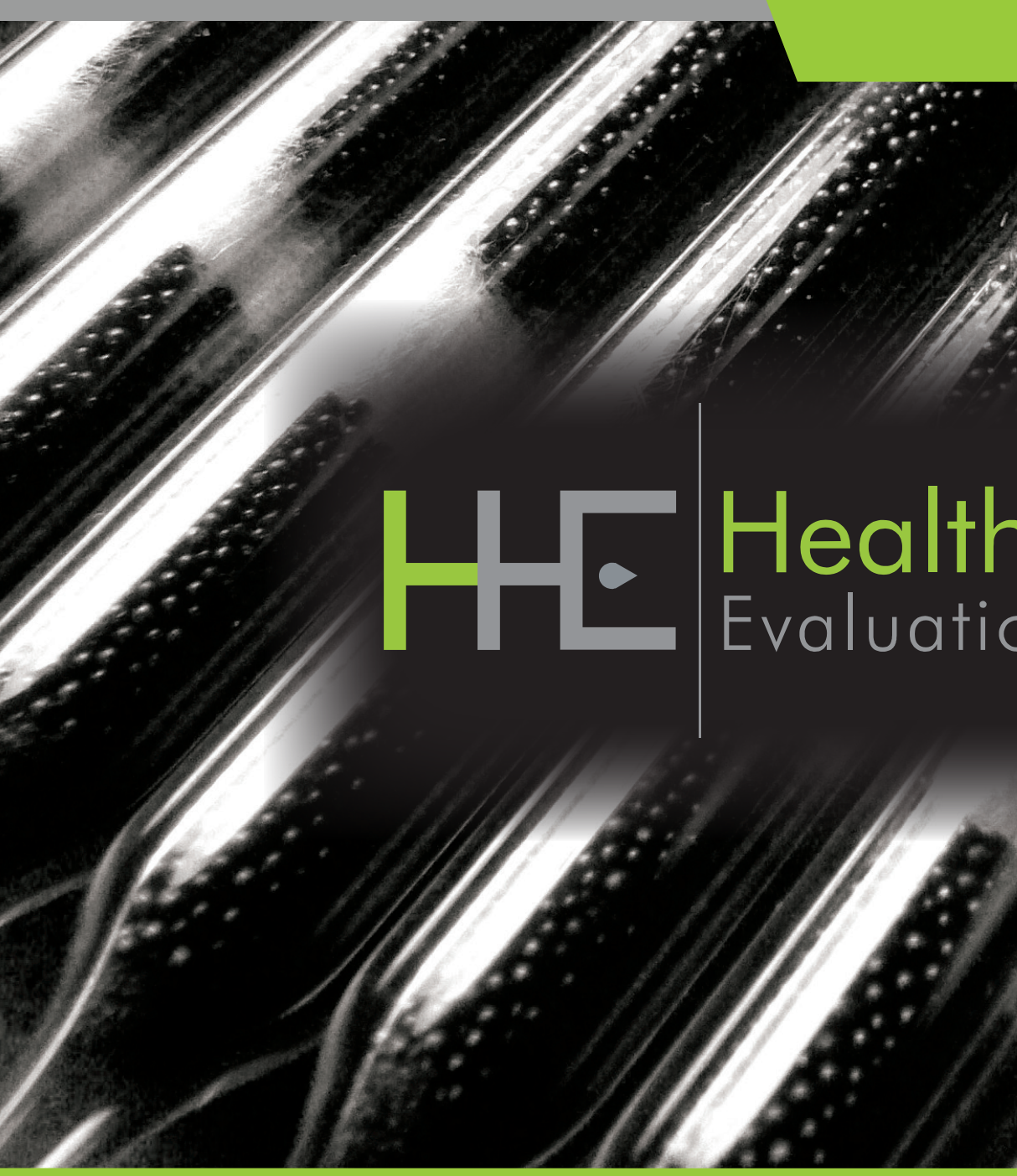

HHE Report No. 2015-0159-3265

December 2016

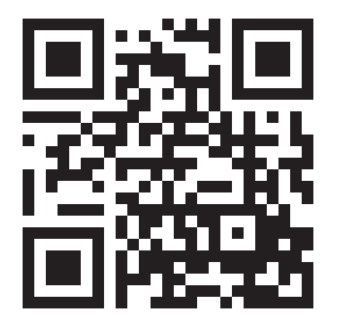

U.S. Department of Health and Human Services Centers for Disease Control and Prevention

National Institute for Occupational Safety and Health

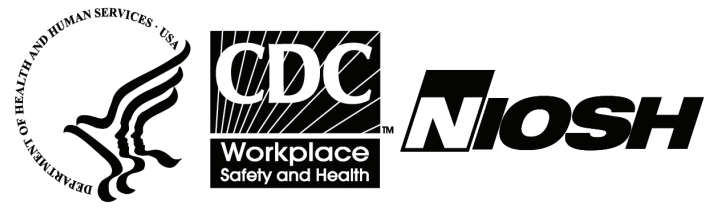




\section{Contents}

Highlights .................................................. i

Abbreviations ...................................... iii

Introduction ............................................ 1

Methods ............................................. 2

Results and Discussion ....................... 3

Conclusions .......................................... 8

Recommendations............................... 8

Appendix A .......................................... 10

Appendix B ........................................ 13

References ........................................ 15

Acknowledgements............................ 19

The employer is required to post a copy of this report for 30 days at or near the workplace(s) of affected employees. The employer must take steps to ensure that the posted report is not altered, defaced, or covered by other material.

The cover photo is a close-up image of sorbent tubes, which are used by the HHE Program to measure airborne exposures. This photo is an artistic representation that may not be related to this Health Hazard Evaluation. Photo by NIOSH. 


\section{Highlights of this Evaluation}

The Health Hazard Evaluation Program received a request from fire fighters at a city fire department. They were concerned that diesel exhaust from fire fighting apparatus could enter the living and sleeping areas of the fire station. They were also concerned about diesel exhaust exposures in the apparatus bay during apparatus start-up and maintenance. We evaluated three fire stations in April 2016.

\section{What We Did}

- We collected air samples for elemental carbon. It is used as a marker of diesel exhaust. We also measured 1-nitropyrene, another chemical found in diesel exhaust.

- We measured carbon monoxide, airborne particle count, and airborne particle size.

- We evaluated airflow patterns.

- We reviewed department injury and illness logs.

\section{What We Found}

- We measured low levels of diesel exhaust in the living areas and apparatus bay at all three fire stations. We found no 1-nitropyrene.

- When the heating, ventilation, and air conditioning systems were running, air flowed from the living area into the apparatus bay. This setup is preferred for keeping chemical exposures low. Carbon monoxide concentrations were low in the living quarters and in the apparatus bays.

- Particle concentrations were low for all particle size ranges measured.

- The injury and illness logs contained very few

We evaluated three fire stations because fire fighters were concerned about exposure to diesel exhaust in the fire station from fire fighting apparatus. We measured low levels of diesel exhaust in the living areas and apparatus bay at all three fire stations. We recommended having the apparatus bay exhaust fans operate automatically when bay doors are opened, moving turnout gear away from apparatus exhaust pipes, and removing exercise equipment from the apparatus bay. entries that could be related to diesel exhaust.

\section{What the Employer Can Do}

- Have the apparatus bay exhaust fans automatically turn on whenever the bay doors are opened and closed.

- Move stored turnout gear away from apparatus exhaust pipes.

- Move the exercise equipment from the apparatus bays to another location in the fire station.

- Train fire fighters to use the NO SMOKE diesel exhaust removal systems properly. 


\section{What Employees Can Do}

- Close apparatus bay doors when equipment is running outside the bay.

- Engage NO SMOKE diesel exhaust removal systems when entering and exiting the fire stations.

- Turn on the apparatus bay exhaust fan system when entering and exiting the fire station.

- Do not place equipment or other items in front of exhaust fans.

- Do not run apparatus or equipment within the apparatus bay longer than necessary. 


\section{Abbreviations}

$\mu \mathrm{g} / \mathrm{m}^{3} \quad$ Micrograms per cubic meter

$\mu \mathrm{m}$

Micrometer

ACGIH®

American Conference of Governmental Industrial Hygienists

$\mathrm{CO}$

Carbon monoxide

CFR

Code of Federal Regulations

HVAC

Heating, ventilation, and air-conditioning

$\mathrm{mg} / \mathrm{m}^{3}$

Milligram per cubic meter

NIOSH

National Institute for Occupational Safety and Health

OEL

Occupational exposure limit

OSHA

Occupational Safety and Health Administration

PM

Particulate matter

ppm

Parts per million

REGEN

Diesel particulate filter and regeneration process

TLV®

Threshold limit value

TWA

Time-weighted average

WEELTM

Workplace environmental exposure level 
This page left intentionally blank 


\section{Introduction}

The Health Hazard Evaluation Program received a request from fire fighters in a city fire department to evaluate potential diesel exhaust exposures. We evaluated three fire stations in April 2016. During the evaluation, we held an opening meeting with city managers and an International Association of Fire Fighters local representative. At the conclusion of the visit, we held a closing meeting with the same participants to discuss our initial findings. We sent interim recommendations in May 2016.

\section{Background}

Each station had an attached living and sleeping quarter that was connected to the apparatus bay by one or more doors. The living quarters included kitchen and eating areas. Table 1 summarizes the fire station designs and types of diesel-powered vehicles housed in each.

Table 1. Fire station design and diesel powered equipment

\begin{tabular}{|c|c|c|c|}
\hline Station No. & $\begin{array}{l}\text { Apparatus } \\
\text { bay design* }\end{array}$ & $\begin{array}{c}\text { Emergency response } \\
\text { vehicles }\end{array}$ & Fire fighting apparatus \\
\hline 10 & Back-in & $\begin{array}{l}\text { Three emergency response } \\
\text { vehicles; Medic unit } \\
\text { (2011 Ford F450 w/10 } \\
\text { cylinder gas engine) }\end{array}$ & $\begin{array}{c}\text { Fire truck (2001 Pierce Dash® w/6 } \\
\text { cylinder Detroit diesel engine)†; } \\
\text { Fire engine ( } 2010 \text { Pierce Velocity } \\
\text { w/6 cylinder Cummins diesel engine) }\end{array}$ \\
\hline 16 & Pull-through & $\begin{array}{c}\text { Two emergency response } \\
\text { vehicles }\end{array}$ & 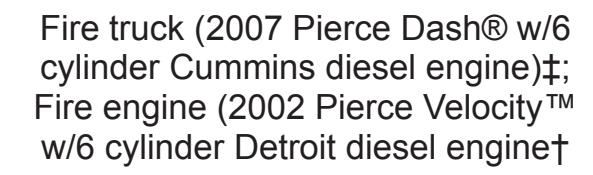 \\
\hline 17 & Pull-through & $\begin{array}{l}\text { Three emergency response } \\
\text { vehicles; Medic unit } \\
\text { (2011 Ford F450 w/10 } \\
\text { cylinder gas engine) }\end{array}$ & $\begin{array}{l}\text { Fire truck (2002 Pierce Dash® w/6 } \\
\text { cylinder Detroit diesel engine); } † \\
\text { Fire engine (2007 Pierce Velocity } \\
\text { w/ } 6 \text { cylinder Cummins diesel engine }\end{array}$ \\
\hline
\end{tabular}

*Back-in design: two bay doors on side next to the street; permanent back wall. Pull-through design: bay doors on the front and back walls.

†Apparatus equipped with Ward Diesel NO SMOKE system.

$\ddagger$ Apparatus equipped with REGEN (diesel particulate filter and regeneration process) system.

All of the diesel powered vehicles used ultra-low sulfur diesel fuel, and the fire engines and fire trucks were equipped with either a Ward Diesel NO SMOKE diesel exhaust reduction system or a diesel particulate filter and regeneration system known as REGEN. The NO SMOKE system, upon startup, diverts engine exhaust through a porous ceramic filter instead of through the exhaust tailpipe. Ceramic filtration continues for a preset amount of time (thus allowing the apparatus to exit the bay). Then, the exhaust is rerouted back through the muffler and out the tailpipe. The REGEN system captures diesel particulate on a filter, then periodically removes the accumulated diesel particulate on the filter by using the heat from the exhaust system. This cleaning process takes between 30 and 45 minutes to complete and the apparatus is out of service during this time. 


\section{Methods}

Our objectives were to:

1. Evaluate diesel exhaust exposures in the fire station apparatus bay and living quarters.

2. Determine if fire fighters had reported any health effects potentially associated with exposure to diesel exhaust.

During the site visit, we observed work practices, workplace conditions, and spoke with the fire fighters at each station. We reviewed the department's injury and illness logs covering events from January 1, 2010-June 30, 2016. Because responses to emergency calls (runs) varied by station, we collected station run sheets that recorded the number of runs, date and time, apparatus, and type of run for the sampled time periods. We also asked fire fighters about using the NO SMOKE and REGEN diesel exhaust controls. We recorded our observations and shared them with closing conference attendees.

\section{Diesel Exhaust, Carbon Monoxide, and Particulates}

Because diesel exhaust is a complex mixture of many gases and particles, we sampled for two substances present in diesel exhaust: elemental carbon and 1-nitropyrene. Elemental carbon is a good marker of exposure because diesel exhaust particulate is typically more than $80 \%$ carbon. The other substance we sampled for, 1-nitropyrene, is a major component of diesel exhaust [Bamford et al. 2003] and is another marker of diesel exhaust. We measured carbon monoxide $(\mathrm{CO})$ because it is a component of most combustion processes.

We collected 29 area air samples for elemental carbon and 1-nitropyrene. Because diesel exhaust exposures can occur away from the fire station, we did not collect personal air samples on fire fighters. Elemental carbon was sampled using National Institute for Occupational Safety and Health (NIOSH) Method 5040 [NIOSH 2016]. We collected 1-nitropyrene air samples using Method 2560 [NIOSH 2016], modified by replacing the chemiluminescence detector with a nitrogen phosphorus detector. We measured $\mathrm{CO}$ throughout the work day with TSI Q-Trak ${ }^{\mathrm{TM}}$ Indoor Air Quality monitors. At each station we placed a $\mathrm{CO}$ monitor in the apparatus bay and in the living quarters.

We measured particle counts using a TSI DustTrak ${ }^{\text {TM }}$ DRX 8533 Aerosol Monitor in the bays and living quarters. We measured particle concentrations in different size groups: particulate matter (PM) smaller than 1 micrometer $(\mu \mathrm{m})(\mathrm{PM} 1)$, PM smaller than $2.5 \mu \mathrm{m}$ (PM2.5), respirable (less than $4 \mu \mathrm{m}$ ), PM smaller than $10 \mu \mathrm{m}$ (PM10), and total PM (less than $100 \mu \mathrm{m})$. We also evaluated particle concentrations in relation to the emergency vehicle dispatch times to evaluate the impact of engine startup on airborne particulate concentrations.

\section{Ventilation}

We used ventilation smoke tubes to observe the airflow between the apparatus bays and living quarters and at doors connecting the apparatus bays to living areas. We also recorded pressure relationships at the doors connecting the apparatus bays and the living areas. We 
tested these areas with the heating, ventilation, and air-conditioning (HVAC) system on and off. The apparatus bay doors were open during each test.

\section{Review of Injury and Illness Logs}

We reviewed injury and illness logs that covered January 1, 2010-June 30, 2015. The logs were extracted from the fire department's workers' compensation data management system.

\section{Results and Discussion}

\section{Diesel Exhaust}

The number of runs per diesel apparatus for each day of our visit is given in Table 2. Our run list does not include those instances when a returning apparatus crew received another call before returning to the station. These runs did not contribute to diesel exhaust exposures within the station.

Table 2. Daily diesel engine apparatus runs

\begin{tabular}{lccc}
\hline Station & Diesel apparatus & April 26, 2016 & April 27, 2016 \\
\hline 10 & Truck & 6 & 2 \\
& Engine & 3 & 1 \\
16 & Truck & 5 & 1 \\
& Engine & 4 & 1 \\
17 & Truck & 5 & 1 \\
& Engine & 8 & 2 \\
\hline
\end{tabular}

At each station, we collected area air samples for approximately 7 to 8 hours during the day. The average elemental carbon air concentrations ranged from 0.43 micrograms per cubic meter $\left(\mu \mathrm{g} / \mathrm{m}^{3}\right)$ to $13 \mu \mathrm{g} / \mathrm{m}^{3}$. Elemental carbon air concentrations for each station are summarized in Table 3. Although these were area air samples, and their results are not directly comparable to occupational exposure limits (OELs), it is helpful to note that these concentrations would not have exceeded the recommended California elemental carbon OEL of $20 \mu \mathrm{g} / \mathrm{m}^{3}$ had they been collected in personal air samples [CDHS 2002]. 
Table 3. Elemental carbon concentrations in $\mu \mathrm{g} / \mathrm{m}^{3}$ area, by station

\begin{tabular}{lcccc}
\hline Date & Sample location & Station 10 & Station 16 & Station 17 \\
\hline $04 / 26 / 2016$ & Living area & 1.5 & 1.2 & 2.0 \\
& Office area & NS & 0.86 & 1.3 \\
& Sleeping quarters & 0.48 & 0.43 & {$[0.46]$} \\
& Apparatus bay \#1 & 7.7 & 0.98 & 1.3 \\
$04 / 27 / 2016$ & Apparatus bay \#2 & 13 & 1.1 & 1.2 \\
& Living area & 1.5 & 1.5 & 2.7 \\
& Office area & NS & 1.0 & 1.5 \\
& Sleeping quarters & 1.3 & 0.66 & $1.0^{*}$ \\
& Apparatus bay \#1 & 8.8 & 1.0 & 1.8 \\
& Apparatus bay \#2 & 10 & 0.91 & 1.9 \\
\hline
\end{tabular}

NS = not sampled

[ ] = Concentration in brackets is between the minimum detectable concentration and minimum quantifiable concentration and has more uncertainty associated with the result.

*Initial sampling pump failed and replacement pump used for duration of air sample. Sampling times from both pumps totaled 278 minutes.

Station 10 had higher elemental carbon concentrations in the apparatus bay compared to Stations 16 and 17. Concentrations in the two Station 10 area samples collected near the apparatus bay back wall $\left(10\right.$ and $\left.13 \mu \mathrm{g} / \mathrm{m}^{3}\right)$ were greater than those collected near the apparatus bay door $\left(7.7\right.$ and $8.8 \mu \mathrm{g} / \mathrm{m}^{3}$ ). Tables B1 through B3 in Appendix B show more detailed sample information for each station and include organic and total carbon results.

At the time of our evaluation, Station 10 had a permanent back wall in the apparatus bay. Stations 16 and 17 were pull-through fire stations that had apparatus bay doors on the front and back of the fire station. This pull-through design allowed more airflow and natural dilution through the apparatus bay when front and back doors were open compared to Station 10.

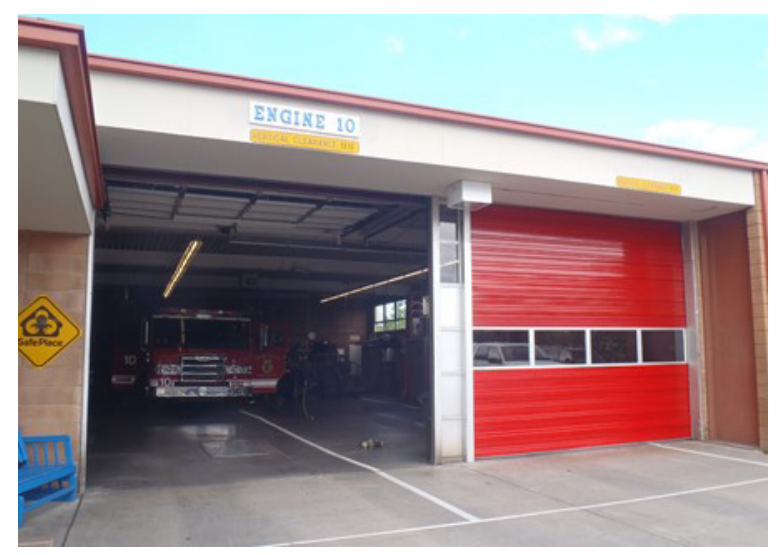

Figure 1. Station 10 apparatus bay doors with permanent back wall. Photo by $\mathrm{NIOSH}$. 
While the elemental carbon concentrations were higher in Station 10's apparatus bay compared to Stations 16 and 17, the living area elemental carbon concentrations were similar in all three stations. The living area elemental carbon concentrations ranged from $0.4 \mu \mathrm{g} / \mathrm{m}^{3}$ to $2.7 \mu \mathrm{g} / \mathrm{m}^{3}$.

For Stations 16 and 17, the office area elemental carbon area air sample concentrations were similar. The office area was not sampled in Station 10. At Station 10, a diesel exhaust and 1-nitropyrene sample were collected in the living quarters located near the Station 10 office area.

We did not detect 1-nitropyrene above the minimum detectable concentration of $0.23 \mu \mathrm{g} / \mathrm{m}^{3}$ in any air sample. The minimum detectable concentration for 1-nitropyrene was calculated by dividing the analytical limit of detection $(0.2 \mu \mathrm{g} / \mathrm{sample})$ by the average volume of air sampled $\left(0.88 \mathrm{~m}^{3}\right)$.

\section{Carbon Monoxide}

The average $\mathrm{CO}$ concentration in the living quarters of the three fire stations was 0.2 parts per million (ppm) while the average CO concentration in the apparatus bays of the three fire stations was $1.2 \mathrm{ppm}$. For perspective, in industrial settings the Occupational Safety and Health Administration (OSHA) has a permissible exposure limit for $\mathrm{CO}$ of $50 \mathrm{ppm}$ timeweighted average (TWA), and the NIOSH CO recommended exposure limit is $35 \mathrm{ppm}$, TWA [NIOSH 2010; OSHA 2016].

We did not observe any increases (more than twice the background level) in CO concentrations within the living or sleeping quarters during apparatus run times. This finding along with the average $\mathrm{CO}$ concentrations reported above, suggests that exhaust from the diesel apparatus was not entering the living and sleeping quarters.

\section{Ventilation Assessment}

The living area at each fire station had a central forced-air HVAC system that was not connected to the apparatus bay. The HVAC systems turned off when the thermostat reached the desired temperature, a design typical in residential settings. Fire fighters mentioned that they routinely turned off the HVAC system during good weather. The HVAC systems had low efficiency pleated air filters (minimum efficiency reporting value less than 10) that appeared clean and properly installed.

When the HVAC system was operating, the living areas in Stations 10 and 16 were under positive pressure relative to the apparatus bay, meaning that air flowed from the living area to the bay, which is preferred. At Station 17, part of the living area (the changing area) was under negative pressure relative to the entrance from the apparatus bay near the ice machine. This means that air flowed from the apparatus bay and into the changing area.

With the HVAC system turned off, the air pressure relationships were the same as above or were neutral (no difference in pressure was noticeable). When the apparatus bay doors were open, wind from outside the station pushed air from the apparatus bay into the living and sleeping quarters, especially during gusty conditions. 
All three stations had an exhaust fan installed on the apparatus bay ceiling. With the apparatus bay doors closed, smoke released on the apparatus bay floor (near the apparatus diesel exhaust) was not entrained by the ceiling exhaust fan. The fan appeared to have little to no impact on the smoke and would not exhaust diesel exhaust released near the apparatus bay floor. In addition, if the ceiling exhaust fans were capturing the diesel exhaust they would pull the diesel exhaust from the floor to the ceiling, right through the breathing zone of a firefighter standing in the apparatus bay, which is not desirable.

In addition to the ceiling fan, Station 17 had a wall-mounted, floor level exhaust fan (Figure 2) that was connected to a timer controlling the wall and ceiling fans. The timer engaged both fans before an apparatus left the station. We released smoke near the exhaust fan and observed that air further than 5-10 feet away did not move with the floor exhaust fan running. We also observed that compressed gas containers were stored in front of the floor exhaust fan, which would diminish the fan's performance.

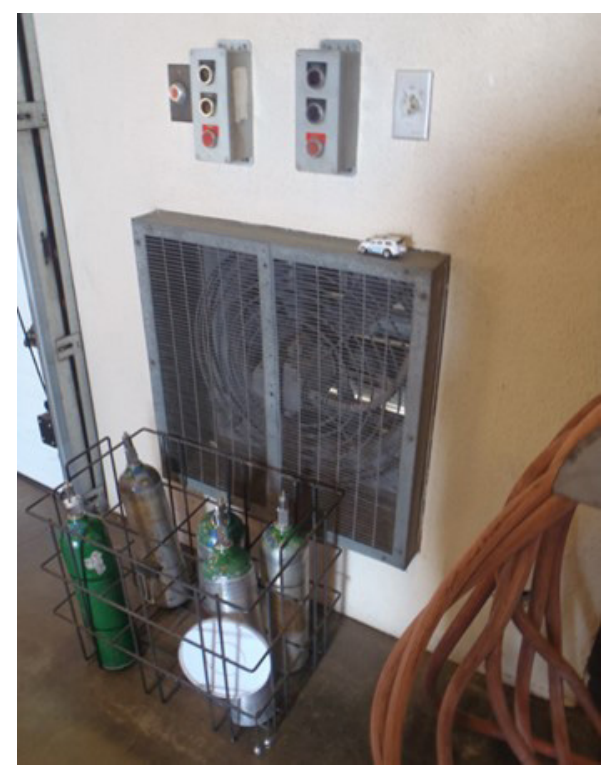

Figure 2. Five small compressed gas cylinders partially blocking the intake of a floor level wall exhaust fan at Station 17. Photo by NIOSH.

For each station, when particle concentrations increased in the apparatus bay, we did not observe a corresponding increase in the living quarters. This indicates that air was not flowing from the apparatus bay into the living quarters during the time period we measured.

We found no correlation between particle concentrations in the living quarters and emergency run times at each station. Table B4 in Appendix B shows the particle size concentrations for Station 10's apparatus bay and living quarters. We chose to show the data from Station 10 data because it had the highest elemental carbon concentrations, giving us the best chance to observe peaks in particle concentrations were they to occur following apparatus startup and departure from the station. 


\section{General Observations}

Fire fighter turnout gear was stored directly across from apparatus exhaust pipes at all three stations (Figure 3). Fire fighters reported that these areas in the apparatus bays were more susceptible to blackening from apparatus exhaust between cleanings.

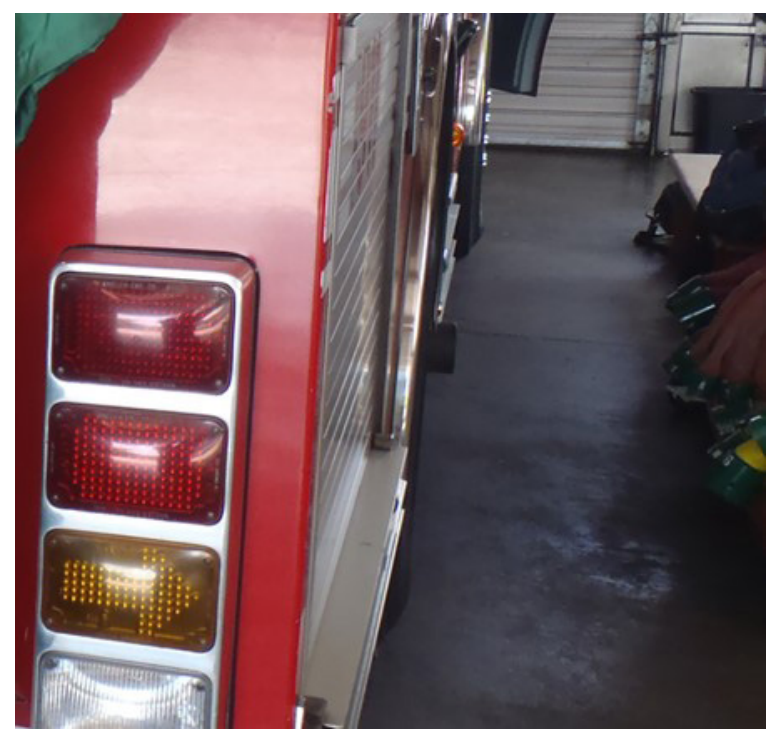

Figure 3. Turnout gear stored near fire engine exhaust in Station 16. Photo by NIOSH.

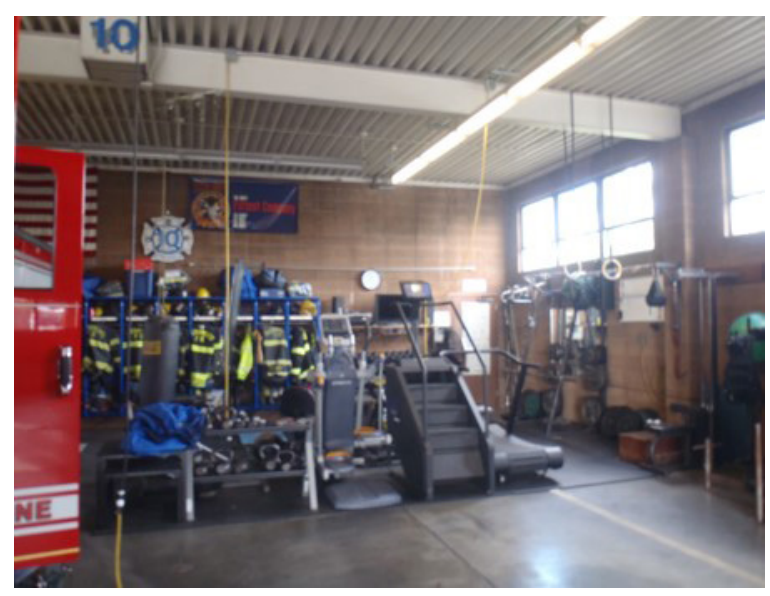

Figure 4. Exercise equipment and gym area in Station 10 apparatus bay. Photo by NIOSH.

During a shift change, all the apparatus and equipment are started to ensure they are in proper working order. The samples collected on April 24, 2016, included a shift change. All of the apparatus were moved outside the apparatus bay to idle with the apparatus bay doors open.

When asked about proper usage of the NO SMOKE and other diesel exhaust control measures, fire fighters reported a range of understanding from not being familiar with the system to having a detailed understanding. They also reported they inconsistently used the apparatus bay exhaust fans. 


\section{Review of Injury and IIIness Logs}

During the period January 1, 2010-June 30, 2015, 235 incidents were recorded in the fire department's workers' compensation data management system. The most common entries were related to musculoskeletal injuries or disorders $(23 \%)$, skin disorders or infections $(19 \%)$, and respiratory infections (7\%). Six entries related to cancer were recorded, including three for skin cancer, two for lymphoma, and one for prostate cancer. There were no reports of lung cancer, which has been associated with exposure to diesel [Air Resources Board 1998; Attfield et al. 2012; Garshick et al. 2004; NIOSH 1988; Silverman et al. 2012; Sun et al. 2014]. Diesel exhaust is considered a Group 1 human carcinogen [IARC 2014]. More information on health effects can be found in Appendix A.

The data management system contained nine entries (4\%) with symptoms that were not otherwise explained and could be consistent with acute symptoms from diesel exhaust exposure. These included six entries of syncope (fainting) or near-syncope (lightheadedness), two entries of eye irritation, and one entry of a chronic cough. However, the reports did not contain details, and these symptoms may have other causes. Symptoms due to diesel exhaust can be non-specific and temporary, causing such things as irritation of the eyes, throat and lungs, cough, headaches, and nausea. As such, these symptoms might be attributed to other causes and may not be reported for entry into the illness or injury logs. It is possible that the illness logs do not entirely capture acute symptoms due to diesel exhaust exposure. Nevertheless, we would not expect symptoms to occur at the diesel exhaust concentrations we found during our visit.

\section{Conclusions}

We found no evidence that diesel exhaust was flowing into the living and sleeping quarters from the apparatus bay in the three fire stations we evaluated. With the exception of one area in Station 17, air flowed from the living and sleeping quarters into the apparatus bay. Although below recommended limits, diesel exhaust concentrations in Station 10's apparatus bay were higher than those in Stations 16 and 17, most likely due to Station 10's back-in only design. Although exposures were low in all the stations, efforts to further reduce exposures are appropriate because of the potential health risks from exposures to diesel exhaust.

\section{Recommendations}

On the basis of our findings, we recommend the actions listed below. We encourage the city to use a labor-management health and safety committee or working group to discuss our recommendations and develop an action plan. Those involved in the work can best set priorities and assess the feasibility of our recommendations for the specific situation at each fire station.

Our recommendations are based on an approach known as the hierarchy of controls. This approach groups actions by their likely effectiveness in reducing or removing hazards. In most cases, the preferred approach is to eliminate hazardous materials or processes and install engineering controls to reduce exposure or shield employees. Until such controls 
are in place, or if they are not effective or feasible, administrative measures and personal protective equipment may be needed.

\section{Engineering Controls}

Engineering controls reduce employees' exposures by removing the hazard from the process or by placing a barrier between the hazard and the employee. Engineering controls protect employees effectively without placing primary responsibility of implementation on the employee.

1. Automate the apparatus bay exhaust fan systems to work in conjunction with opening and closing the bay doors.

2. Close apparatus bay doors when equipment is running outside of the bay. This is especially important during shift change when all the equipment is running at once.

3. Consider local exhaust ventilation systems that attach directly to apparatus diesel exhaust in the back-in only station.

\section{Administrative Controls}

The term administrative controls refers to employer-dictated work practices and policies to reduce or prevent hazardous exposures. Their effectiveness depends on employer commitment and employee acceptance. Regular monitoring and reinforcement are necessary to ensure that policies and procedures are followed consistently.

1. Train the fire fighters periodically on the proper use of the NO SMOKE diesel exhaust removal systems and best practices.

2. Review NO SMOKE diesel exhaust removal system maintenance records to ensure the exhaust systems are properly maintained according to manufacturer's specifications.

3. Store turnout gear away from diesel engine exhaust pipes.

4. Consistently maintain positive pressure in the Station 17 changing area relative to the ice machine area in the apparatus bay. This means that air flows from the changing area into the bay.

5. Move the exercise equipment from the apparatus bays to another location in the fire station.

6. Coordinate training sessions on cancer risk factors, cancer screening, and the measures fire fighters can take to reduce exposure.

More general information on cancer can be found on the American Cancer Society website at http://www.cancer.org and the National Cancer Institute website at http://www.cancer.gov. 


\section{Appendix A: Occupational Exposure Limits}

NIOSH investigators refer to mandatory (legally enforceable) and recommended OELs for chemical, physical, and biological agents when evaluating workplace hazards. OELs have been developed by federal agencies and safety and health organizations to prevent adverse health effects from workplace exposures. Generally, OELs suggest levels of exposure that most employees may be exposed to for up to 10 hours per day, 40 hours per week, for a working lifetime, without experiencing adverse health effects. However, not all employees will be protected if their exposures are maintained below these levels. Some may have adverse health effects because of individual susceptibility, a pre-existing medical condition, or a hypersensitivity (allergy). In addition, some hazardous substances act in combination with other exposures, with the general environment, or with medications or personal habits of the employee to produce adverse health effects. Most OELs address airborne exposures, but some substances can be absorbed directly through the skin and mucous membranes.

Most OELs are expressed as a TWA exposure. A TWA refers to the average exposure during a normal 8- to 10-hour workday. Some chemical substances and physical agents have recommended short-term exposure limit or ceiling values. Unless otherwise noted, the shortterm exposure limit is a 15-minute TWA exposure. It should not be exceeded at any time during a workday. The ceiling limit should not be exceeded at any time.

In the United States, OELs have been established by federal agencies, professional organizations, state and local governments, and other entities. Some OELs are legally enforceable limits; others are recommendations.

- The U.S. Department of Labor OSHA permissible exposure limits (29 CFR 1910 [general industry]; 29 CFR 1926 [construction industry]; and 29 CFR 1917 [maritime industry]) are legal limits. These limits are enforceable in workplaces covered under the Occupational Safety and Health Act of 1970.

- NIOSH recommended exposure limits are recommendations based on a critical review of the scientific and technical information and the adequacy of methods to identify and control the hazard. NIOSH recommended exposure limits are published in the NIOSH Pocket Guide to Chemical Hazards [NIOSH 2010]. NIOSH also recommends risk management practices (e.g., engineering controls, safe work practices, employee education/training, personal protective equipment, and exposure and medical monitoring) to minimize the risk of exposure and adverse health effects.

- Other OELs commonly used and cited in the United States include the threshold limit values (TLVs), which are recommended by American Conference of Governmental Industrial Hygienists $(\mathrm{ACGIH} \otimes)$, a professional organization, and the workplace environmental exposure level (WEELs), which are recommended by the American Industrial Hygiene Association, another professional organization. The TLVs and WEELs are developed by committee members of these associations from a review of the published, peer-reviewed literature. These OELs are not consensus standards. TLVs are considered voluntary exposure guidelines for use by industrial hygienists and others trained in this discipline "to assist in the control of health hazards" [ACGIH 2016]. 
WEELs have been established for some chemicals "when no other legal or authoritative limits exist" [AIHA 2016].

Outside the United States, OELs have been established by various agencies and organizations and include legal and recommended limits. The Institut für Arbeitsschutz der Deutschen Gesetzlichen Unfallversicherung (Institute for Occupational Safety and Health of the German Social Accident Insurance) maintains a database of international OELs from European Union member states, Canada (Québec), Japan, Switzerland, and the United States. The database, available at http://www.dguv.de/ifa/GESTIS/GESTIS-Internationale-Grenzwerte-fürchemische-Substanzen-limit-values-for-chemical-agents/index-2.jsp, contains international limits for more than 2,000 hazardous substances and is updated periodically.

OSHA requires an employer to furnish employees a place of employment free from recognized hazards that cause or are likely to cause death or serious physical harm [Occupational Safety and Health Act of 1970 (Public Law 91-596, sec. 5(a)(1))]. This is true in the absence of a specific OEL. It also is important to keep in mind that OELs may not reflect current health-based information.

When multiple OELs exist for a substance or agent, NIOSH investigators generally encourage employers to use the lowest OEL when making risk assessment and risk management decisions. NIOSH investigators also encourage use of the hierarchy of controls approach to eliminate or minimize workplace hazards. This includes, in order of preference, the use of (1) substitution or elimination of the hazardous agent, (2) engineering controls (e.g., local exhaust ventilation, process enclosure, dilution ventilation), (3) administrative controls (e.g., limiting time of exposure, employee training, work practice changes, medical surveillance), and (4) personal protective equipment (e.g., respiratory protection, gloves, eye protection, hearing protection). Control banding, a qualitative risk assessment and risk management tool, is a complementary approach to protecting employee health. Control banding focuses on how broad categories of risk should be managed. Information on control banding is available at http://www.cdc.gov/niosh/topics/ctrlbanding/. This approach can be applied in situations where OELs have not been established or can be used to supplement existing OELs.

\section{Diesel Exhaust}

Diesel exhaust is a complex mixture of gases and particles expelled from diesel engines. Diesel exhaust is typically black in color with a low odor threshold (easily detected at low concentrations) and contains more than 40 toxic compounds [Environmental Protection Agency 2002]. Diesel exhaust particles are composed of microscopic elemental carbon with organic carbon compounds adsorbed on them [NIOSH 1988; OSHA 1988]. These particles range in size including fine particles $(0-2.5 \mu \mathrm{m}$ in aerodynamic diameter including a high proportion of ultrafine particles $(<0.1 \mu \mathrm{m}$ in aerodynamic diameter)) [Wichmann 2007]. The gaseous portion of diesel exhaust contains such gases as nitrogen oxides, sulfur oxides, and carbon oxides [NIOSH 1988; OSHA 1988].

Exposure to diesel exhaust has been associated with acute and chronic respiratory effects and lung cancer [Environmental Protection Agency 2002]. Acute health effects of diesel exhaust 
exposure include irritation of the eyes, nose, throat, and lungs, and it can cause cough, headache, lightheadedness, and nausea [Gamble et al. 1987; Pronk et al. 2009; Reger and Hancock 1980; Sydbom et al. 2001]. Exposure to diesel exhaust can also cause inflammation in the lungs, which may aggravate chronic respiratory symptoms and asthma. Chronic exposures are associated with cough, increased sputum production, and lung function changes [Sydbom et al. 2001; Ulfvarson and Alexandersson 1990]. Whether a person experiences these acute or chronic health effects depends on the duration and magnitude of the exposures and on individual susceptibility.

Diesel exhaust is considered a Group 1 human carcinogen [IARC 2014]. On the basis of the results of laboratory animal and human epidemiology studies, NIOSH considers whole diesel exhaust emissions a potential occupational carcinogen [NIOSH 1988]. Human epidemiology studies suggest an association between occupational exposure to whole diesel exhaust emissions and lung cancer [Air Resources Board 1998; Attfield et al. 2012; Garshick et al. 2004; NIOSH 1988; Silverman et al. 2012; Sun et al. 2014], while studies of rats and mice exposed to whole diesel exhaust, and especially to the particulate portion, confirm an association with lung tumors [Air Resources Board 1998; NIOSH 1988; OSHA 1988]. NIOSH has stated that "excess cancer risk for workers exposed to diesel exhaust has not yet been quantified, but the probability of developing cancer should be reduced by minimizing exposure" [NIOSH 1988].

1-nitropyrene, a nitrated polycyclic aromatic hydrocarbon, is a combustion byproduct emitted in diesel engine exhaust [Rosenkranz 1982]. 1-nitropyrene has been used as a marker of exposure to diesel PM [Galaviz et al. 2015; Miller-Schulze et al. 2010]. The International Agency for Research on Cancer classified 1-nitropyrene as "probably carcinogenic to humans (Group 2A)" in 2014 [IARC 2014]. It has also been identified as a potential mutagen [Chan 1996; Scheepers et al. 1995]. Other human health effects from 1-nitropyrene exposures are not well known.

OSHA permissible exposure limits exist for nitrogen monoxide, nitrogen dioxide, sulfur dioxide, and CO. However, at the present time, no OSHA permissible exposure limit exists for diesel exhaust. In 2002, the California Department of Public Health recommended a $20 \mu \mathrm{g} / \mathrm{m}^{3}$ OEL for diesel exhaust (as elemental carbon) [CDHS 2002]. However, the California OSHA State Plan does not have an OEL for diesel exhaust. 


\section{Appendix B: Tables}

Table B1. Station 10 area air sampling for diesel exhaust

\begin{tabular}{lccccc}
\hline Date & Sample location & $\begin{array}{c}\text { Sample } \\
\text { duration } \\
\text { (minutes) }\end{array}$ & $\begin{array}{c}\text { Elemental } \\
\text { carbon } \\
\left(\mu \mathrm{g} / \mathrm{m}^{3}\right)\end{array}$ & $\begin{array}{c}\text { Organic } \\
\text { carbon } \\
\left(\mu \mathrm{g} / \mathrm{m}^{3}\right)\end{array}$ & $\begin{array}{c}\text { Total } \\
\text { carbon } \\
\left(\mu \mathrm{g} / \mathrm{m}^{3}\right)\end{array}$ \\
\hline 04/26/2016 & Living area & 432 & 1.5 & 25 & 27 \\
& Sleeping quarters & 444 & 0.48 & 10 & 11 \\
$04 / 27 / 2016$ & Near bay door & 431 & 7.7 & 22 & 30 \\
& Near back bay wall & 442 & 13 & 32 & 45 \\
& Living Area & 450 & 1.5 & 22 & 24 \\
& Sleeping quarters & 454 & 1.3 & 15 & 16 \\
& Near bay door & 456 & 8.8 & 18 & 27 \\
& Near back bay wall & 463 & 10 & 21 & 31 \\
\hline
\end{tabular}

Table B2. Station 17 area air sample results for diesel exhaust

\begin{tabular}{lccccc}
\hline Date & Sample location & $\begin{array}{c}\text { Sample } \\
\text { duration } \\
(\text { minutes })\end{array}$ & $\begin{array}{c}\text { Elemental } \\
\text { carbon } \\
\left(\mu \mathrm{g} / \mathrm{m}^{3}\right)\end{array}$ & $\begin{array}{c}\text { Organic } \\
\text { carbon } \\
\left(\mu \mathrm{g} / \mathrm{m}^{3}\right)\end{array}$ & $\begin{array}{c}\text { Total } \\
\text { carbon } \\
\left(\mu \mathrm{g} / \mathrm{m}^{3}\right)\end{array}$ \\
\hline $04 / 26 / 2016$ & 474 & 2.0 & 49 & 51 \\
& Living area & 474 & 1.3 & 33 & 34 \\
& Office area & 466 & {$[0.5]$} & 12 & 12 \\
$04 / 27 / 2016$ & Sleeping quarters & 1.3 & 15 & 16 \\
& Bay: outside living area door & 468 & 1.2 & 18 & 19 \\
& Bay: outside sleeping quarters door & 468 & 2.7 & 120 & 120 \\
& Living area & 420 & 1.5 & 49 & 51 \\
& Office area & 424 & 1.0 & 14 & 15 \\
& Sleeping quarters & $278^{*}$ & 1.8 & 21 & 23 \\
Bay: outside living area & 421 & 1.9 & 22 & 24 \\
\hline
\end{tabular}

*Pump failure. Replacement pump was used for duration of sample.

[ ] = Concentration in brackets is between the minimum detectable and minimum quantifiable concentration and has more uncertainty associated with the result. 
Table B3. Station 16 area air sampling for diesel exhaust

\begin{tabular}{|c|c|c|c|c|c|}
\hline Date & Sample location & $\begin{array}{c}\text { Sample } \\
\text { duration } \\
\text { (minutes) }\end{array}$ & $\begin{array}{c}\text { Elemental } \\
\text { carbon } \\
\left(\mu \mathrm{g} / \mathrm{m}^{3}\right)\end{array}$ & $\begin{array}{l}\text { Organic } \\
\text { carbon } \\
\left(\mu \mathrm{g} / \mathrm{m}^{3}\right)\end{array}$ & $\begin{array}{l}\text { Total } \\
\text { carbon } \\
\left(\mu \mathrm{g} / \mathrm{m}^{3}\right)\end{array}$ \\
\hline \multirow[t]{5}{*}{ 04/26/2016 } & Living area & 433 & 1.2 & 27 & 28 \\
\hline & Office area & 443 & 0.86 & 21 & 22 \\
\hline & Sleeping quarters & 444 & 0.43 & 14 & 14 \\
\hline & Bay: work bench near parking lot & 433 & 1.0 & 21 & 22 \\
\hline & Bay: work bench near street & 436 & 1.1 & 21 & 22 \\
\hline \multirow[t]{5}{*}{ 04/27/2016 } & Living area & 453 & 1.5 & 24 & 26 \\
\hline & Office area & 450 & 1.0 & 21 & 22 \\
\hline & Sleeping quarters & 460 & 0.66 & 13 & 14 \\
\hline & Bay: work bench near parking lot & 465 & 1.0 & 19 & 20 \\
\hline & Bay: work bench near street & 457 & 0.91 & 18 & 19 \\
\hline
\end{tabular}

Table B4. Station 10 particle size measurements $\left(\mathrm{mg} / \mathrm{m}^{3}\right)$

\begin{tabular}{lcccccc}
\hline Particle size fraction & \multicolumn{3}{c}{ Living quarters } & \multicolumn{3}{c}{ Apparatus bay } \\
& Average & Minimum & Maximum & Average & Minimum & Maximum \\
\hline $\mathrm{PM}_{1}$ & 0.034 & ND & 0.64 & 0.029 & 0.01 & 2.2 \\
$\mathrm{PM}_{2.5}$ & 0.035 & ND & 0.66 & 0.030 & 0.01 & 2.2 \\
Respirable & 0.035 & ND & 0.66 & 0.031 & 0.01 & 2.3 \\
$\mathrm{PM}_{10}$ & 0.036 & ND & 0.67 & 0.040 & 0.01 & 3.6 \\
Total & 0.039 & ND & 0.67 & 0.064 & 0.01 & 7.3 \\
\hline
\end{tabular}

$\mathrm{mg} / \mathrm{m}^{3}=$ milligram per cubic meter

$\mathrm{ND}=$ not detected 


\section{References}

ACGIH [2016]. 2016 TLVs ${ }^{\circledR}$ and BEIs ${ }^{\circledR}$ : threshold limit values for chemical substances and physical agents and biological exposure indices. Cincinnati, OH: American Conference of Governmental Industrial Hygienists.

AIHA [2016]. AIHA 2016 emergency response planning guidelines (ERPG) \& workplace environmental exposure levels (WEEL) handbook. Fairfax, VA: American Industrial Hygiene Association.

Air Resource Board [1998]. The report on diesel exhaust. Sacramento, California: California Environmental Protection Agency, California Air Resources Board (ARB). April 22, 1998.

Attfield MD, Schleiff PL, Lubin JH, Blair A, Stewart PA, Vermeulen R, Coble JB, Silverman DT [2012]. The diesel exhaust in miners study: a cohort mortality study with emphasis on lung cancer. J Natl Cancer Inst 104(11):869-883, http://dx.doi.org/10.1093/jnci/djs035.

Bamford HA, Bezabeh DZ, Schantz S, Wise SA, Baker JE [2003]. Determination and comparison of nitrated-polycyclic aromatic hydrocarbons measured in air and diesel particulate reference materials. Chemosphere 50(5):575-587.

CDHS [2002]. Health hazard advisory: diesel engine exhaust. Oakland, California: Hazard Evaluation System and Information Service, California Department of Health Services (CDHS), Occupational Health Branch, http://www.cdph.ca.gov/programs/hesis/Documents/diesel.pdf.

CFR. Code of Federal Regulations. Washington, DC: U.S. Government Printing Office, Office of the Federal Register.

Chan P [1996]. NTP technical report on the toxicity studies of 1-nitropyrene (CAS No. 552243-0) Administered by Inhalation to F344/N Rats. Toxic Rep Ser Apr(34):1-D2.

Environmental Protection Agency [2002]. Health assessment document for diesel engine exhaust. Washington, DC: National Center for Environmental Assessment, Office of Transportation and Air Quality, U.S. Environmental Protection Agency (EPA) Publication No. EPA/600/8-90/057F.

Galaviz VE, Quintana PJ, Yost MG, Sheppard L, Paulsen MH, Camp JE, Simpson CD [2015]. Urinary metabolites of 1-nitropyrene in US-Mexico border residents who frequently cross the San Ysidro Port of Entry. J Expo Sci Environ Epidemiol, http://dx.doi.org/10.1038/jes.2015.78.

Gamble J, Jones W, Mishall S [1987]. Epidemiological-environmental study of diesel bus garage workers: acute effects of $\mathrm{NO} 2$ and respirable particulate on the respiratory system. Environ Res 42(1):201-214.

Garshick E, Laden F, Hart JE, Rosner B, Smith TJ, Dockery D, Speizer FE [2004]. Lung cancer in railroad workers exposed to diesel exhaust. Environ Health Perspect 112(15):15391543, http://dx.doi.org/10.1289/ehp.7195. 
IARC [2014]. Diesel and gasoline engine exhausts and some nitroarenes. IARC Monographs on the Evaluation of Carcinogenic Risks to Humans, No. 105, http:/www.ncbi.nlm.nih.gov/books/NBK294270/.

Miller-Schulze JP, Paulsen M, Toriba A, Tang N, Hayakawa K, Tamura K, Dong L, Zhang X, Simpson CD [2010]. Exposures to particulate air pollution and nitro-polycyclic aromatic hydrocarbons among taxi drivers in Shenyang, China. Environ Sci Technol 44(1):216-221, http://dx.doi.org/10.1021/es802392u.

NIOSH [1988]. Current intelligence bulletin 50: carcinogenic effects of exposure to diesel exhaust. Cincinnati, OH: U.S. Department of Health and Human Services, Centers for Disease Control, National Institute for Occupational Safety and Health, DHHS (NIOSH) Publication No. 88-116.

NIOSH [2010]. NIOSH pocket guide to chemical hazards. Cincinnati, OH: U.S. Department of Health and Human Services, Centers for Disease Control and Prevention, National Institute for Occupational Safety and Health, DHHS (NIOSH) Publication No. 2010-168c, http://www.cdc.gov/niosh/npg/.

NIOSH [2016]. NIOSH manual of analytical methods (NMAM). 5th ed. O'Connor PF, Ashley K, eds. Cincinnati, OH: U.S. Department of Health and Human Services, Centers for Disease Control and Prevention, National Institute for Occupational Safety and Health, DHHS (NIOSH) Publication No. 2014-151, http://www.cdc.gov/niosh/nmam.

OSHA [1988]. Hazard information bulletin on potential carcinogenicity of diesel exhaust. Washington, DC; U.S. Department of Labor, Occupational Safety and Health Administration. OSHA Bulletin 19881130.

OSHA [2016]. OSHA sampling and analytical methods. Hendricks W, ed. Salt Lake City, UT: U.S. Department of Labor, Occupational Safety and Health Administration, http://www.osha.gov/dts/sltc/methods/index.html.

Pronk A, Coble J, Stewart PA [2009]. Occupational exposure to diesel engine exhaust: a literature review. J Expo Sci Environ Epidemiol 19(5):443-457, http://dx.doi.org/10.1038/jes.2009.21.

Reger R, Hancock J [1980]. Coal miners exposed to diesel exhaust emissions. In: Rom W, Archer V, eds. Health implications of new energy technologies. Ann Arbor, MI: Ann Arbor Science Publishers, Inc., pp. 212-231.

Rosenkranz H [1982]. Direct-acting mutagens in diesel exhausts: magnitude of the problem. Mutat Res 101(1):1-10.

Scheepers PT, Martens MH, Velders DD, Fijneman P, van Kerkhoven M, Noordhoek J, Bos RP [1995]. 1-nitropyrene as a marker for the mutagenicity of diesel exhaust-derived particulate matter in workplace atmospheres. Environ Mol Mutagen 25(2):134-147. 
Silverman DT, Samanic CM, Lubin JH, Blair AE, Stewart PA, Vermeulen R, Coble JB, Rothman N, Schleiff PL, Travis WD, Ziegler RG, Wacholder S, Attfield MD [2012]. The diesel exhaust in miners study: a nested case-control study of lung cancer and diesel exhaust. J Natl Cancer Inst 104(11):855-868, http://dx.doi.org/10.1093/jnci/djs034.

Sun Y, Bochmann F, Nold A, Mattenklott M [2014]. Diesel exhaust exposure and the risk of lung cancer - a review of the epidemiological evidence. Int J Environ Res Public Health 11(2):1312-1340, http://dx.doi.org/10.3390/ijerph110201312.

Sydbom A, Blomberg A, Parnia S, Stenfors N, Sandström T, Dahlén SE [2001]. Health effects of diesel exhaust emissions. Eur Respir J 17(4):733-746.

Ulfvarson U, Alexandersson R [1990]. Reduction in adverse effect on pulmonary function after exposure to filtered diesel exhaust. Am J Ind Med 17(3):341-347, http://dx.doi.org/10.1002/ajim.4700170306.

Wichmann HE [2007]. Diesel exhaust particles. Inhal Toxicol 19(Suppl 1):241-244, http://dx.doi.org/10.1080/08958370701498075. 
Keywords: North American Industry Classification System 922160 (Fire Protection), California, Fire Fighter, Fire Station, Diesel Exhaust, Ventilation, Elemental Carbon, 1-nitropyrene 
The Health Hazard Evaluation Program investigates possible health hazards in the workplace under the authority of the Occupational Safety and Health Act of 1970 (29 U.S.C. § 669(a) (6)). The Health Hazard Evaluation Program also provides, upon request, technical assistance to federal, state, and local agencies to investigate occupational health hazards and to prevent occupational disease or injury. Regulations guiding the Program can be found in Title 42, Code of Federal Regulations, Part 85; Requests for Health Hazard Evaluations (42 CFR Part 85).

\section{Disclaimer}

The recommendations in this report are made on the basis of the findings at the workplace evaluated and may not be applicable to other workplaces.

Mention of any company or product in this report does not constitute endorsement by NIOSH.

Citations to Web sites external to NIOSH do not constitute NIOSH endorsement of the sponsoring organizations or their programs or products. NIOSH is not responsible for the content of these Web sites. All Web addresses referenced in this document were accessible as of the publication date.

\section{Acknowledgments}

Desktop Publisher: Shawna Watts

Editor: Ellen Galloway

Logistics: Donnie Booher, Kevin Moore

\section{Availability of Report}

Copies of this report have been sent to the employer and employees at the facility. The state and local health department and the Occupational Safety and Health Administration Regional Office have also received a copy. This report is not copyrighted and may be freely reproduced.

\section{Recommended citation for this report:}

NIOSH [2016]. Evaluation of diesel exhaust exposures at multiple fire stations in a city fire department. By Couch J, de Perio MA, Broadwater K. Cincinnati, OH: U.S. Department of Health and Human Services, Centers for Disease Control and Prevention, National Institute for Occupational Safety and Health, NIOSH Health Hazard Evaluation Report 2015-0159-3265, http://www.cdc.gov/niosh/hhe/reports/pdfs/2015-0159-3265.pdf. 
Delivering on the Nation's promise:

Safety and health at work for all people through research and prevention

To receive NIOSH documents or more information about occupational safety and health topics, please contact NIOSH:

Telephone: 1-800-CDC-INFO (1-800-232-4636)

TTY: 1-888-232-6348

CDC INFO: www.cdc.gov/info

or visit the NIOSH Web site at www.cdc.gov/niosh

For a monthly update on news at $\mathrm{NIOSH}$, subscribe to $\mathrm{NIOSH}$ eNews by visiting www.cdc.gov/niosh/eNews. 